Original research article

\title{
Induction of caspase-mediated apoptosis using Alnus japonica extracts in AGS human gastric carcinoma cells
}

\author{
Seong-Eun Kimª, Yon-Suk Kim ${ }^{\mathrm{a}, \mathrm{c}}$, Woen-Bin Shin ${ }^{\mathrm{a}, \mathrm{b}}$, Jin-Su Park ${ }^{\mathrm{a}, \mathrm{b}}$, Sang-Ho Moon ${ }^{\mathrm{c}, \mathrm{d}}$, \\ Byong-Tae Jeon ${ }^{\mathrm{e}}$, Pyo-Jam Park ${ }^{\mathrm{a}, \mathrm{b}, \mathrm{c}, *}$ \\ a Konkuk University, Department of Biotechnology, Chungju, South Korea \\ ${ }^{\mathrm{b}}$ Konkuk University, Department of Applied Life Science, Chungju, South Korea \\ ${ }^{\mathrm{c}}$ Konkuk University, Medicinal Biological Resources Research Institute, Chungju, South Korea \\ ${ }^{\mathrm{d}}$ Konkuk University, Division of Food Bio Science, Chungju, South Korea \\ e Hasung Corp., Seoul, South Korea
}

\section{A R T I C L E I N F O}

\section{Article history:}

Received 24 August 2016

Received in revised form 21 April 2017

Accepted 31 January 2018

Available online 9 February 2018

\section{Keywords:}

Alnus japonica

Antioxidant

Apoptosis

AGS human gastric carcinoma cells

Caspase-dependent pathway

\begin{abstract}
A B S T R A C T
Alnus japonica has been used as a traditional oriental medicine for many diseases such as fever, haemorrhage and alcoholism. In this study, A. japonica extracts were evaluated for their in vitro antioxidant potentials and anticancer effects in AGS human gastric carcinoma cell line. The antioxidant properties of $A$. japonica extracts were evaluated using several biochemical assays, including FRAP (ferric reducing antioxidant power) assay, ABTS (2, 2'-azino-bis (3-ethylbenzothiazoline-6-sulphonic acid)), DPPH (2,2-diphenyl-1-picrylhydrazyl), alkyl and hydroxyl radical scavenging activity assay. Our study showed that ethanol extract of A. japonica (AJE) has a more potent antioxidant activity than its water extract. In addition, AJE extract inhibited the cell growth and induced the cell death by increasing reactive oxygen species (ROS) production in AGS cells. Moreover, AJE extract specifically triggered the apoptosis mediated through the activation of caspase-8, 7, 3, and poly-ADP ribose polymerase (PARP). Thus, these results suggest that AJE extract could be potentially useful as a new promising strategy in the therapy for gastric carcinoma cancer.
\end{abstract}

(C) 2018 Faculty of Health and Social Sciences, University of South Bohemia in Ceske Budejovice. Published by Elsevier Sp. z o.o. All rights reserved.

\section{Introduction}

There are many reports on the positive correlation between antioxidant activity and cytotoxicity in cancer cells of plant extracts, including Plinia edulis, Mutellina purpurea L., Polygonum tinctorium Lour., and Sygygium fruticosum Roxb (Heo et al., 2014; Sieniawska et al., 2013). Some plant extracts found to exhibit significant cytotoxicity in cancer cell lines are considered as potential anticancer agents. Such activity is ideally specific to the cancer cells but not to the normal cells. Gastric cancer is the second most common cause of cancer-related mortality worldwide and the fourth most prevalent cancer (Jemal et al., 2011). At present, surgery, radiation therapy, conventional chemotherapy, molecular targeted therapy, and biological therapy are used to manage gastric cancer; however, due to numerous side-effects, such as

\footnotetext{
* Author for correspondence: Konkuk University, Department of Biotechnology, Chungju 27478, South Korea.

E-mail address: parkpj@kku.ac.kr (P.-J. Park).
}

myelosuppression, hepatotoxicity, and immunosuppression, the curative effects of existing chemotherapeutic drugs are unsatisfactory (Ali et al., 2013; Leite de Oliveira et al., 2012). Therefore, it is getting important to search for new drugs from natural sources that have the capability of preventing and treating gastric cancer without or with minimum harmful side-effects to the patients. Several researchers have proposed to use traditional medicines, especially those derived from medicinal plants which could be used to increase the efficacy of anticancer drugs and decrease their toxicity or side effects (Zhang et al., 2013). Chemoprevention refers to administration of synthetic or naturally occurring agents to prevent the initiation and/or promotion of events associated with carcinogenesis and it has been increasingly appreciated as an effective approach for the management of neoplasia (Ahmad et al., 2001).

Apoptosis, or programmed cell death, is a mechanism by which cells die in response to DNA damage or to control cell proliferation. There are two major mechanisms of cell death such as necrosis and apoptosis. Cells that are damaged by external injury undergo necrosis; whereas, cells which are induced to commit programmed 
death by internal or external stimuli undergo apoptosis (Ghobrial et al., 2005).

A. japonica, an indigenous Alnus species in Korea, North China, and Japan, is a deciduous, ovate elliptic-leaved tree that grows in wet lowlands and mountainous areas. The Alnus species has been recognised as a traditional Asian herbal medicine and it has been extensively used as a remedy for fever, haemorrhage, diarrhoea, and alcoholism (Lee, 1966). Previous studies on A. japonica extracts have led to the identification of numerous clinically relevant characteristics, including reduced atopic dermatitis (Joo et al., 2009), hepatoprotective effect and antioxidant effect (Kim et al., 2004). However, despite these protective properties, A. japonica's ability to induce apoptosis in gastric carcinoma has not been studied. Therefore, the purpose of this study was to elucidate the molecular mechanism underlying the apoptosis induced by ethanol extract of $A$. japonica (AJE) in AGS human gastric carcinoma cells.

\section{Materials and methods}

\section{Reagents}

2,2'-azino-bis (3-ethylbenzothiazoline-6-sulfonic acid) as diammonium salt (ABTS), 2,4,6-tripyridyl triazine (TPTZ), 2,2'-azobis (2-amidinopropane hydrochloride) (AAPH), (4-pyridyl-1-oxide)$\mathrm{N}$-tert-butylnitrone (4-POBN), 5,5-dimethyl-1-pyrroline- $\mathrm{N}$-oxide (DMPO), 2',7'-dichlorofluorescein-diacetate $\left(\mathrm{DCFH}_{2}-\mathrm{DA}\right)$, and Hoechst 33342 were purchased from Sigma Chemical Co. (St. Louis, MO, USA). Dulbecco's Modified Eagle's Medium (DMEM) and RPMI-1640 were purchased from Hyclone (Thermo scientific, Logan, UT). Antibodies for Bax and Bcl-2 were obtained from Santa Cruz Biotechnology (Santa Cruz, CA). Cleaved caspase-8, 3, 7, and poly-ADP ribose polymerase (PARP) anti-rabbit and anti-mouse peroxidase-conjugated secondary antibodies were obtained from Cell Signalling (Cell Signalling Technology, MA, USA). A. japonica was purchased from local herbal medicine market (Jecheon, Korea). All other reagents were of the highest grade available commercially.

\section{Preparation of A. japonica extracts}

Water and ethanol extracts of $A$. japonica bark were prepared as described below. Briefly, the water extract (AJW) was obtained by decocting $A$. japonica dried bark powder $(100 \mathrm{~g})$ with distilled water $(1000 \mathrm{ml})$ for $2 \mathrm{~h}$ using an electric brewing pot (JS research Inc., Gongju, Korea) and ethanol extract (AJE) was prepared by shaking $A$. japonica dried bark powder ( $100 \mathrm{~g}$ ) with $70 \%$ ethanol $(1000 \mathrm{ml})$ for 1 day at $25^{\circ} \mathrm{C}$ in a shaking incubator (Daewongbio, Goesan, Korea) for two times. Then, extracts were filtered through Whatman No. 41 filter paper under suction at room temperature. The filtered extracts were evaporated under reduced pressure using a rotary vacuum evaporator (EYELA, Tokyo, Japan) at $40^{\circ} \mathrm{C}$. After evaporation, the extracts were lyophilized in a freeze-dryer (Samwon, Busan, Korea) and stored at $-20^{\circ} \mathrm{C}$ until use.

\section{ABTS [2,2'-azino-bis(3-ethylbenzothiazoline-6-sulphonic acid)]} radical cation $(A B T S+)$ scavenging

The ABTS assay was performed as described previously (Re et al., 1999) with slight modifications. The working solution was prepared by mixing the two stock solutions (7.4 mM ABTS solution and $2.6 \mathrm{mM}$ potassium persulfate solution) in equal quantities and allowing them to react in the dark for $15 \mathrm{~h}$ at room temperature (R.T.). ABTS reagent $(900 \mu \mathrm{l})$ was mixed with $100 \mu \mathrm{l}$ of extract, and the absorbance was measured at $414 \mathrm{~nm}$ after 30 min of reaction time at R.T., using ethanol as the blank sample. Antioxidant activity was expressed by Trolox equivalent antioxidant capacity (TEAC), as millimoles Trolox equivalents ( $\mathrm{mM}$ Trolox eq/mg extract).

FRAP (ferric reducing antioxidant power) assay

FRAP assay was carried out by the method reported by Benzie \& Strain (Benzie and Strain, 1996) with slight modifications. One milliliter of FRAP reagent $(1 \mathrm{ml}$; mixture of $0.3 \mathrm{M}$ acetate buffer, $10 \mathrm{mM} \mathrm{TPTZ}$ in $40 \mathrm{mM} \mathrm{HCl}$, and $20 \mathrm{mM} \mathrm{FeCl}_{3}(10: 1: 1 \mathrm{v} / \mathrm{v} / \mathrm{v})$ was mixed with $50 \mu \mathrm{l}$ of extract and allowing them to react at $37^{\circ} \mathrm{C}$ for $5 \mathrm{~min}$. The absorbance was determined at $593 \mathrm{~nm}$ against distilled water as the blank. A calibration curve was obtained using an aqueous solution of ferrous sulphate $\left(\mathrm{FeSO}_{4}\right)$. The FRAP values were expressed as $\mathrm{mM} \mathrm{FeSO}_{4}$ equivalent per milligram of extract ( $\mathrm{mM} \mathrm{FeSO}_{4}$ eq/mg extract).

\section{Radical scavenging activity by ESR (Electron spin resonance) spectrometry}

DPPH (2,2-diphenyl-1-picrylhydrazyl) radical scavenging activity was measured using an ESR spectrometer (JES-FA machine; JOEL, Tokyo, Japan) according to the technique described by Nanjo et al. (1996). Sample (30 $\mu \mathrm{l})$ was added to $30 \mu \mathrm{l}$ of DPPH $(60 \mu \mathrm{M})$ in methanol. After $10 \mathrm{~s}$ of vigorous mixing, solutions were transferred to Teflon capillary tubes and inserted into the cavity of the ESR spectrometer. The spin adducts were determined by ESR spectrometer exactly after $2 \mathrm{~min}$.

In addition, the alkyl radicals were generated by AAPH. The phosphate-buffered saline (PBS) reaction mixture containing $40 \mathrm{mM}$ AAPH and $40 \mathrm{mM}$ 4-POBN was incubated with different concentrations of samples at $37^{\circ} \mathrm{C}$ in a water bath for $30 \mathrm{~min}$ and then they were transferred to $100 \mu$ l Teflon capillary tubes and spin adducts were analysed.

The hydroxyl radicals were generated via the Fenton reaction and reacted rapidly with nitrone spin trap DMPO. The resulted DMPO-OH adducts were detected using an ESR spectrometer. The reaction mixture containing $100 \mu \mathrm{l}$ of $0.3 \mathrm{M}$ DMPO, $100 \mu \mathrm{l}$ of $10 \mathrm{mM} \mathrm{FeSO}_{4}$, and $100 \mu \mathrm{l}$ of $10 \mathrm{mM}$ hydrogen peroxide $\left(\mathrm{H}_{2} \mathrm{O}_{2}\right)$ was mixed with the samples and then transferred to Teflon capillary tubes. The spin adducts were measured by an ESR spectrometer exactly after $2.5 \mathrm{~min}$.

\section{Determination of total polyphenol and total flavonoid contents}

Total polyphenol content (TPC) was determined using FolinCiocalteu assay (Singleton et al., 1999). Total flavonoid content (TFC) was determined by aluminum colorimetric method (Zhishen et al., 1999) with slight modifications. Briefly, the samples were individually dissolved in distilled water $(100 \mu \mathrm{g} / \mathrm{ml})$. Then, $50 \mu \mathrm{l}$ of these solutions were mixed with $250 \mu \mathrm{l}$ of distilled water and $15 \mu \mathrm{l}$ of $5 \% \mathrm{NaNO}_{2}$ and allowed to react for $5 \mathrm{~min}$. Following this, $30 \mu \mathrm{l}$ of $10 \% \mathrm{AlCl}_{3}$ was added, and the mixture was allowed to stand for $6 \mathrm{~min}$. Finally, $100 \mu \mathrm{l}$ of $1 \mathrm{M} \mathrm{NaOH}$ and $55 \mu \mathrm{l}$ of distilled water were added to the reaction mixture. After $10 \mathrm{~min}$ incubation at ambient temperature, the absorbance of the supernatant was measured at $510 \mathrm{~nm}$ against the blank in the spectrophotometer (Tecan, Mannedorf, Switzerland). The TFC was calculated based on the calibration curve of catechin. Total flavonoid contents were expressed as milligram catechin equivalents per micro gram of dry extract ( $\mathrm{mg} \mathrm{CE} / \mu \mathrm{g}$ extract).

\section{Cell culture}

Human normal hepatic (Chang), human gastric epithelial carcinoma (AGS), human gastric polygonal carcinoma (SNU1967), and human gastric epithelial carcinoma (SNU-601) cell 
lines were obtained from the American Type Culture Collection (ATCC, Rockville, MD, USA) and Korean Cell Line Bank (KCLB, Seoul, Korea). Chang cells were maintained in DMEM with $10 \%$ inactivated FBS and $1 \%$ penicillin-streptomycin-neomycin at $37{ }^{\circ} \mathrm{C}$ in a humidified incubator containing $5 \% \mathrm{CO}_{2}$. AGS, SNU1967, and SNU-601 cells were grown in RPMI-1640 medium supplemented with $10 \%$ inactivated FBS, $2.05 \mathrm{mM}$-glutamine, and $1 \%$ penicillin-streptomycin-neomycin at $37{ }^{\circ} \mathrm{C}$ in a humidified incubator containing $5 \% \mathrm{CO}_{2}$. Cultures were harvested, and cell numbers were counted using a hemocytometer. Experiments were determined using trypan blue exclusion and examined using phase contrast microscopy.

\section{Cell viability analysis}

The cytotoxicity assay was performed using Thiazolyl Blue Tetrazolium Bromide method as described with minor modifications. Briefly, Chang cells $\left(1.5 \times 10^{4}\right.$ cells/well $)$, AGS cells $\left(2.0 \times 10^{4}\right.$ cells/well), SNU-1967 cells $\left(2.0 \times 10^{4}\right.$ cells/well $)$, and SNU-601 cells $\left(2.0 \times 10^{4}\right.$ cells/well $)$ were seeded in 48 -well microtiter plates and then exposed to different concentrations of AJE extract and doxorubicin $(2 \mu \mathrm{M})$ for 12,24 , and $36 \mathrm{~h}$, respectively. Doxorubicin was employed as a positive control. Following 12, 24, and $36 \mathrm{~h}$ of cell treatment, treatment medium was completely removed from all wells and $200 \mu \mathrm{l}$ of fresh media supplemented with $8 \mu \mathrm{l}$ of MTT stock solution $(50 \mathrm{mg} / \mathrm{ml})$ was added to each well and incubated for $3 \mathrm{~h}$ at $37^{\circ} \mathrm{C}$. Subsequently, the resulted formazan crystal products were dissolved by the addition of $200 \mu$ l of DMSO. The absorbance at $540 \mathrm{~nm}$ was measured using a microplate reader (SpectraMax M2/M2e, CA, USA).

\section{Observation of morphological changes}

AGS cells $\left(4 \times 10^{5}\right.$ cells/well) were seeded in $60 \mathrm{~mm}$ dishes, incubated for $12 \mathrm{~h}$, and then exposed to different concentrations of AJE extract and doxorubicin $(2 \mu \mathrm{M})$ as a positive control for $24 \mathrm{~h}$. Cellular morphology was observed using a phase contrast microscope (Nikon, Japan).

\section{Cell cycle analysis by flow cytometry}

Cellular DNA levels were determined using flow cytometry analyses of propidium iodide (PI)-labeled cells (Kim et al., 2012). In brief, AGS cells ( $4 \times 10^{5}$ cells/well) were seeded into $60 \mathrm{~mm}$ dishes, incubated for $12 \mathrm{~h}$, and then exposed to different concentrations of AJE extract and doxorubicin $(2 \mu \mathrm{M})$ for $24 \mathrm{~h}$. After incubation, cells were washed twice with PBS and re-suspended in PBS containing $1 \%$ PI and $0.1 \%$ ribonuclease $\mathrm{A}$ (RNase $\mathrm{A}$ ) at $37^{\circ} \mathrm{C}$ for $30 \mathrm{~min}$. FACSCalibur flow cytometer (Becton \& Dickinson Co., USA) was used for the flow cytometry analyses. The cell cycle analysis was performed using CellQuest software (BD Biosciences).

\section{Observation of nuclear morphologic changes using Hoechst 33342 staining}

Nuclear Hoechst 33342 staining was used to investigate changes in the nuclear morphology of apoptotic cells. AGS cells $\left(1 \times 10^{4}\right.$ cells/well) were seeded on an 8 well chamber slide, incubated for $12 \mathrm{~h}$, and then exposed to different concentrations of AJE extract and doxorubicin $(2 \mu \mathrm{M})$ for $24 \mathrm{~h}$. The cells were washed twice with PBS and then fixed in PBS containing 4\% paraformaldehyde for $30 \mathrm{~min}$ at R.T. The fixed cells were washed with PBS containing $0.02 \%$ tween 20 . Cells were stained with Hoechst 33342 $(1 \mu \mathrm{g} / \mathrm{ml})$ in the dark for $20 \mathrm{~min}$ at R.T. Cells were then washed thrice with PBS and the Hoechst 33342-stained nuclei were visualized under a fluorescence microscope (Carl Zeiss, UY, USA).

\section{Annexin V-FITC/PI apoptosis assay}

Cellular DNA levels were determined using flow cytometry analyses of PI-labeled cells using the annexin V-FITC apoptosis detection kit (BD Bioscience, CA, USA). AGS cells ( $4 \times 10^{5}$ cells/well) were seeded in $60 \mathrm{~mm}$ dishes, incubated for $12 \mathrm{~h}$, and then exposed to different concentrations of AJE extract and doxorubicin $(2 \mu \mathrm{M})$ for $24 \mathrm{~h}$. Cells were harvested, washed twice with PBS, and resuspended in $500 \mu \mathrm{l}$ of binding buffer at a concentration of $1 \times 10^{6}$ cells $/ \mathrm{ml}$. The Cells were then incubated with $5 \mu \mathrm{l}$ of annexin V-FITC and $5 \mu \mathrm{l}$ of PI in the dark for $15 \mathrm{~min}$ at ambient temperature and analysed by FACSCalibur flow cytometer (Becton \& Dickinson Co., USA). Events were recorded statistically (10,000 events/sample) using CellQuest software (BD Biosciences).

\section{Measurement of intracellular ROS by flow cytometry}

Intracellular ROS accumulation was detected via flow cytometry using the cell-permeable fluorogenic probe $\mathrm{DCFH}_{2}$-DA, which is a stable nonpolar dye which can easily diffuse into the cell and it can be hydrolyzed by intracellular esterase yielding $2^{\prime}, 7^{\prime}$-dichlorodihydrofluorescin (DCFH) within the cell. $\mathrm{DCFH}_{2}$-DA is nonfluorescence, but when this reagent is oxidised by ROS, it becomes green fluorescence. Briefly, AGS cells $\left(4 \times 10^{5}\right.$ cells/well) were seeded in $60 \mathrm{~mm}$ dishes, incubated for $12 \mathrm{~h}$, and then exposed to different concentrations of AJE extract and doxorubicin $(2 \mu \mathrm{M})$ for $24 \mathrm{~h}$. After treatment, the cells were incubated with medium containing $10 \mu \mathrm{M} \mathrm{DCFH} \mathrm{D}_{2}$-DA at $37^{\circ} \mathrm{C}$ for $30 \mathrm{~min}$. Then, the cells were harvested and re-suspended in $1 \mathrm{ml}$ of PBS. Samples were analysed by FACSCalibur flow cytometer (Becton \& Dickinson Co., USA). Data were analysed using CellQuest software (BD Biosciences).

\section{Western blot analysis}

After treatment, cells were washed once with PBS and then lysed using ice-cold RIPA buffer. Cell lysates were centrifuged at $13,000 \mathrm{~g}$ for $30 \mathrm{~min}$ at $4{ }^{\circ} \mathrm{C}$. Proteins were separated by $12 \%$ sodium dodecyl sulfate polyacrylamide gel electrophoresis (SDS-PAGE) and transferred to polyvinylidene difluoride (PVDF) membranes. The membrane was blocked with $5 \%(\mathrm{v} / \mathrm{v})$ nonfat dry milk in Trisbuffered saline with Tween 20 (TBST; $10 \mathrm{mM}$ Tris-HCl, $150 \mathrm{mM}$ $\mathrm{NaCl}$, and $0.1 \%$ Tween 20, pH 7.5) at R.T. for $1 \mathrm{~h}$. This was followed by an overnight incubation of membrane at $4{ }^{\circ} \mathrm{C}$ with $1: 1000$ dilution of protein-specific primary antibodies (Bax, Bcl-2, cleaved caspase-8, 7, 3, PARP and cleaved PARP). The membrane was washed thrice with TBST for 5 min each. The membrane was incubated again with the appropriate horseradish peroxidase (HRP)-conjugated secondary antibodies at R.T. for $1 \mathrm{~h}$ and washed again three times with TBST buffer. The membrane was then incubated with ECL substrate solution for $5 \mathrm{~min}$ and visualised with autoradiography film. The imaging program Luminescent image analyser (LAS-3000; Fujifilm, Tokyo, Japan) was used for quantification.

\section{Statistical analysis}

Data were expressed as the mean \pm standard deviation (SD). Experimental data were analysed statistically using one-way analysis of variance (ANOVA) for multiple group comparisons. A probability value of ${ }^{*} p<.05,{ }^{* *} p<.01$, or ${ }^{* * *} p<.001$ were considered statistically significant. And data were analyzed by two-tailed unpaired $t$-test. Values of $p<.05$ were considered statistically significant. Each experiment was performed in triplicates (GraphPad-Prism Software Inc., San Diego, CA). 


\section{Results and discussion}

The antioxidant properties of A. japonica extracts

Many concrete pieces of evidence have demonstrated that natural products have the capacity to be an important source of antioxidants which prevent many diseases including carcinogenesis (Milaeva, 2011).

Secondary plant metabolites, especially phenolic compounds have been found to be strong antioxidants. Antioxidants could scavenge or suppress the reactive oxygen species (ROS) and reactive nitrogen species (RNS) formation and enhance the antioxidant defence systems in the body; consequently, it could lead to preventing carcinogenesis (Halliwell, 2007).

The antioxidant capacities of $A$. japonica water and ethanol extracts are shown in Table 1. Trolox equivalent antioxidant capacity (TEAC) is measured through hydrogen donors, which can terminate oxidation process by converting free radicals into stable forms (Re et al., 1999). According to our data, there is no significant different between ABTS radical cation scavenging activities of water and ethanol extracts of $A$. japonica (Table 1 ). The FRAP assay is commonly used to evaluate antioxidant capacity due to its rapid, simple, and sensitive nature. The antioxidant potentials of processed and unprocessed extracts are estimated from their ability to reduce the TPTZ-Fe (III) complex to a TPTZ-Fe (II) complex. In this study, the ethanol extract showed higher FRAP antioxidant activity than the water extract. Moreover, various radical scavenging activities against DPPH, alkyl and hydroxyl radicals were estimated using an ESR spectrometer. DPPH has been widely used to evaluate various antioxidant substances' free radical scavenging abilities (Kim et al., 2014). As shown in Table 1 , $\mathrm{DPPH}$ assay half maximal inhibitory concentrations ( $\mathrm{IC}_{50}$ ) of water and ethanol extracts were $5.0 \pm 2.0$ and $4.0 \pm 1.0 \mu \mathrm{g} / \mathrm{ml}$, respectively. Thus, the both water and ethanol extracts displayed greater antioxidant activity. The alkyl radical spin adducts of 4-POBN/free radicals were generated from AAPH, and a decrease in ESR signals

Table 1

Extraction yields, FRAP antioxidant activity, various radical scavenging activity (ABTS, DPPH, alkyl, and hydroxyl), and total polyphenol and flavonoid content of $A$. japonica extracts.

\begin{tabular}{|c|c|c|c|c|c|c|c|c|}
\hline Solvent & $\begin{array}{l}\text { Extraction } \\
\text { yields (\% } \\
\text { W/W) }\end{array}$ & $\begin{array}{l}\text { TEAC (mM } \\
\text { Trolox eq./mg } \\
\text { extract) }\end{array}$ & $\begin{array}{l}\mathrm{FRAP}(\mathrm{mM} \\
\mathrm{FeSO}_{4} \text { eq./mg } \\
\text { extract) }\end{array}$ & $\begin{array}{l}\text { DPPH radical } \\
\text { scavenging activity } \\
\mathrm{IC}_{50}(\mathrm{mg} / \mathrm{ml}) \\
\end{array}$ & $\begin{array}{l}\text { Alkyl radical } \\
\text { scavenging activity } \\
\mathrm{IC}_{50}(\mathrm{mg} / \mathrm{ml})\end{array}$ & $\begin{array}{l}\text { Hydroxyl radical } \\
\text { scavenging activity } \\
\mathrm{IC}_{50}(\mathrm{mg} / \mathrm{ml}) \\
\end{array}$ & $\begin{array}{l}\text { Total polyphenol } \\
\text { content (mg GAE/100 } \\
\mu \text { g extract) }\end{array}$ & $\begin{array}{l}\text { Total flavonoid } \\
\text { content (mg CE } / 100 \\
\mu \text { g extract) }\end{array}$ \\
\hline Water & 4.69 & $0.936 \pm 0.00$ & $2.042 \pm 0.03$ & $0.005 \pm 0.002$ & $0.020 \pm 0.004$ & $0.441 \pm 0.001$ & $97.651 \pm 0.364$ & $0.019 \pm 0.001$ \\
\hline Ethanol & 3.77 & $0.924 \pm 0.01^{\mathrm{ns}}$ & $5.626 \pm 0.01^{* * *}$ & $0.004 \pm 0.001^{\mathrm{ns}}$ & $0.016 \pm 0.002^{\mathrm{ns}}$ & $0.459 \pm 0.002$ & $122.492 \pm 0.765^{* * *}$ & $0.036 \pm 0.000^{* * *}$ \\
\hline
\end{tabular}

GAE: Gallic acid equivalents, CE: Catechin equivalents, TEAC: Trolox equivalent antioxidant capacity, FRAP: ferric reducing antioxidant power.

Each value is the mean \pm SD of three determinations $\left({ }^{* * *} p<.001\right.$ vs. water extract).
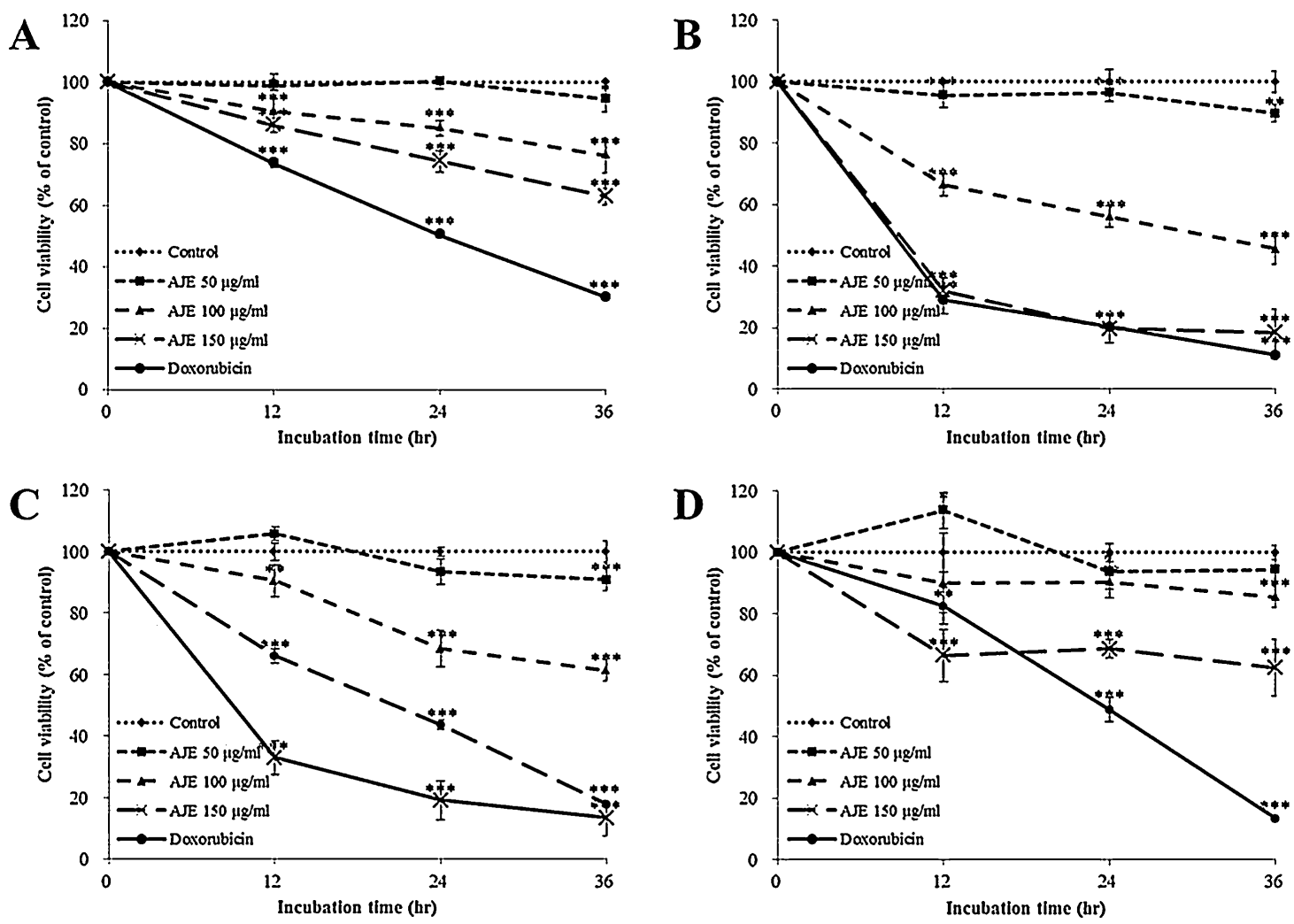

Fig. 1. Dose-dependent and time-dependent effects of Alnus japonica ethanol (AJE) extract on the cell viability of various cell lines. (A) Chang human normal hepatic cells; (B) AGS human gastric carcinoma cells; (C) SNU-1967 human gastric carcinoma cells; (D) SNU-601 human gastric carcinoma cells. Results are expressed as the percentage of the cell viability relative to the viability of control. Each value is the mean \pm SD of three determinations $\left({ }^{*} p<.05,{ }^{* *} p<.01\right.$ and ${ }^{* * *} p<.001$ vs. control). 
was observed with the dose-dependent increases in both water and ethanol extracts. Ethanol extract exhibited stronger alkyl radical scavenging activity than water extract. The hydroxyl radicals generated in a $\mathrm{Fe}^{2+} / \mathrm{H}_{2} \mathrm{O}_{2}$ system were trapped by a DMPO forming spin adduct, which could be detected by an ESR spectrometer, and the typical 1:2:2:1 ESR signal of the DMPO$\mathrm{OH}$ adduct was observed. The $\mathrm{IC}_{50}$ values of hydroxyl radical scavenging activity of water and ethanol extracts were $441.0 \pm 1.0$ and $459.0 \pm 2.0 \mu \mathrm{g} / \mathrm{ml}$ respectively.

These results indicate that ethanol extract from $A$. japonica effectively scavenged various reactive radicals.

\section{Total polyphenol and flavonoid contents}

A. japonica water and ethanol extraction yields were 4.69 and $3.77(\% \mathrm{w} / \mathrm{w}$ ) respectively (Table 1 ). The total polyphenol contents of water and ethanol extracts were $97.651 \pm 0.364 \mathrm{mg} \mathrm{GAE} / 100 \mu \mathrm{g}$ and $122.492 \pm 0.765 \mathrm{mg}$ GAE $/ 100 \mu \mathrm{g}$ respectively. Similarly, the total flavonoid content of ethanol extract was markedly higher than that of water extract (Table 1). Our results showed that ethanol extract with higher total polyphenol and flavonoid contents than water extract. Recent evidence demonstrated that phenols, namely flavonoids, appear to be beneficial compounds in various stages of carcinogenesis (Clere et al., 2011).

\section{Effects of AJE extract on the cell viability}

The effects of AJE extract on the cell viability of human tumor and non-tumour cells were determined as shown in Fig. 1. AJE extract reduced the cell viability in time and dose-dependent manners.The $\mathrm{IC}_{50}$ values of $24 \mathrm{~h}$ treatment were $>150 \mu \mathrm{g} / \mathrm{ml}$ in Chang cells (Fig. 1A), $116.99 \mu \mathrm{g} / \mathrm{ml}$ in AGS cells (Fig. 1B), $137.38 \mu \mathrm{g} / \mathrm{ml}$ in SNU-1967 cells (Fig. 1C), and $>150 \mu \mathrm{g} / \mathrm{ml}$ in SNU-601 cells (Fig. 1D). More precisely, AJE extract profoundly reduced the cell viability in AGS cells compared to Chang, SNU1967, and SNU-601 cells. When the cells were treated with ascending concentration range of AJE extract from 50 to $150 \mu \mathrm{g} / \mathrm{ml}$ for $24 \mathrm{~h}$, the cell viability (\% of control) of Chang cells (nontumorigenic) was decreased from $100.32 \pm 0.95 \%$ to $74.42 \pm 3.48 \%$, whereas the cell viability of AGS cells (tumorigenic) was reduced from $96.40 \pm 2.75 \%$ to $19.68 \pm 4.57 \%$. As a positive control, all four cell lines used in this study were treated with doxorubicin, a cancer chemotherapy drug. These results indicated that AJE extract might be less cytotoxic to non-tumorigenic cells. The present data also suggested that AJE extract has stronger and broader inhibitory effects on the growth of cancer cells than non-tumorigenic cells. Similar to our results, it had been reported that the aqueous extract of Plinia edulis leaves, which contain high amounts of polyphenols and flavonoids possess cytotoxic activity and inhibit cell growth of MCF-7 cells (Carvalho et al., 2012). Based on the cell viability analysis, we selected the doses and times for the following experiments.

\section{Morphologic changes and cell death in AGS cells}

In the present study, we examined the morphological changes and the cell death induced by AJE extract in AGS cells. Following the cell exposure to toxicants, the most readily observed effect is a morphological alteration in the cell-layer and/or cell-shape in monolayer cultures (Ekwall et al., 1990). The effect of AJE extract on the cell morphology of AGS cell line was markedly induced in a dose-dependent manner (Fig. 2). The AJE extract induced significant morphological abnormalities in AGS cells, which were characteristic features of cell death including cell shrinkage, detachment from neighbouring cells and reduced cell density (Fig. 2A). Cell membrane integrity assessment and counting of living and dead cells were performed using trypan blue dye exclusion technique. This dye does not enter living cells, but it passes through the membranes of dead cells. The AGS cell number $\left(10^{5}\right)$ was significantly decreased by AJE extract treatment in a dose-dependent manner after exposing to $24 \mathrm{~h}$ (control; $15.5 \pm 0.9$, AJE $50 \mu \mathrm{g} / \mathrm{ml} ; 14.6 \pm 0.9$, AJE $100 \mu \mathrm{g} / \mathrm{ml} ; 7.4 \pm 0.9$,
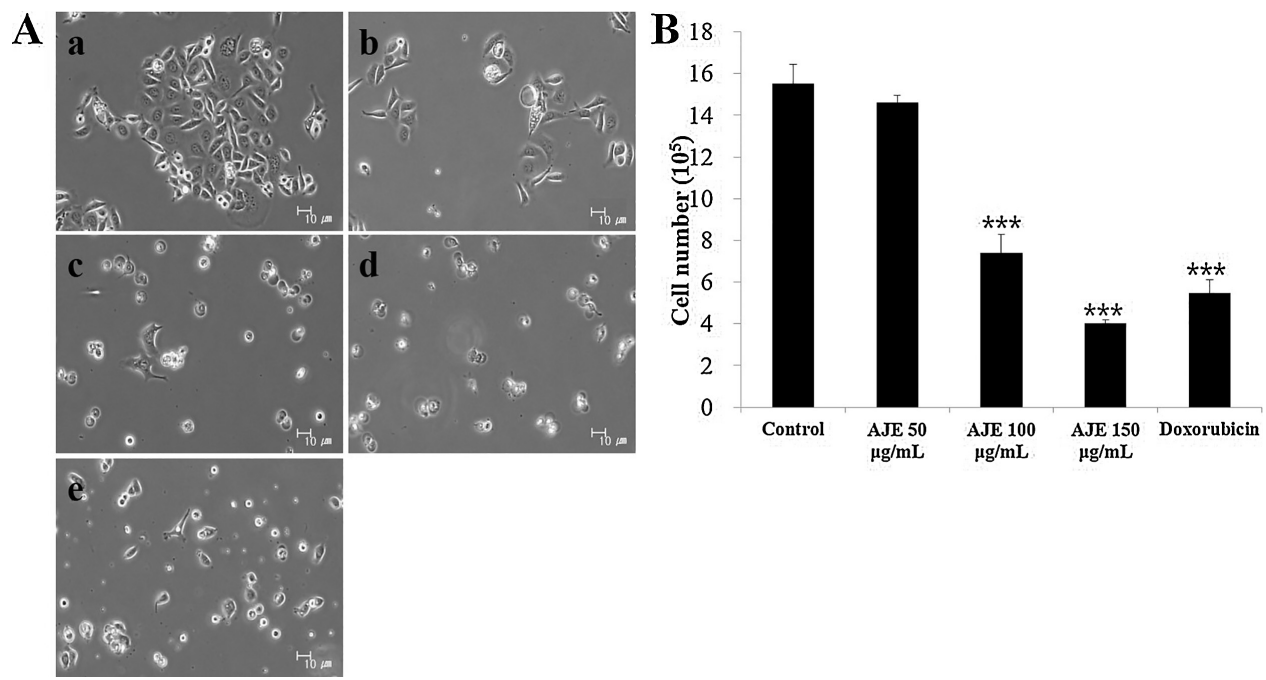

Fig. 2. Induction of morphologic changes and cell death by Alnus japonica ethanol (AJE) extract in AGS cells. (A) Observation of morphological changes. Cells were treated with (a) 0, (b) AJE $50 \mu \mathrm{g} / \mathrm{ml}$, (c) AJE $100 \mu \mathrm{g} / \mathrm{ml}$, (d) AJE $150 \mu \mathrm{g} / \mathrm{ml}$, and (e) doxorubicin ( $2 \mu \mathrm{M}$ ), and morphological changes were monitored after $24 \mathrm{~h}$. Morphological changes were observed under a phase-contrast microscope. Photographs were taken using a phase-contrast microscope at $100 \times$ magnification. Scale bar: $10 \mu \mathrm{m}$. (B) Direct living cell counting was performed by trypan blue exclusion assay. Results are expressed as the cell number $\left(10^{5}\right)$. Each value is the mean \pm SD of three determinations $(* * * p<.001$ vs. control). (For interpretation of the references to colour in this figure legend, the reader is referred to the web version of this article.) 
A
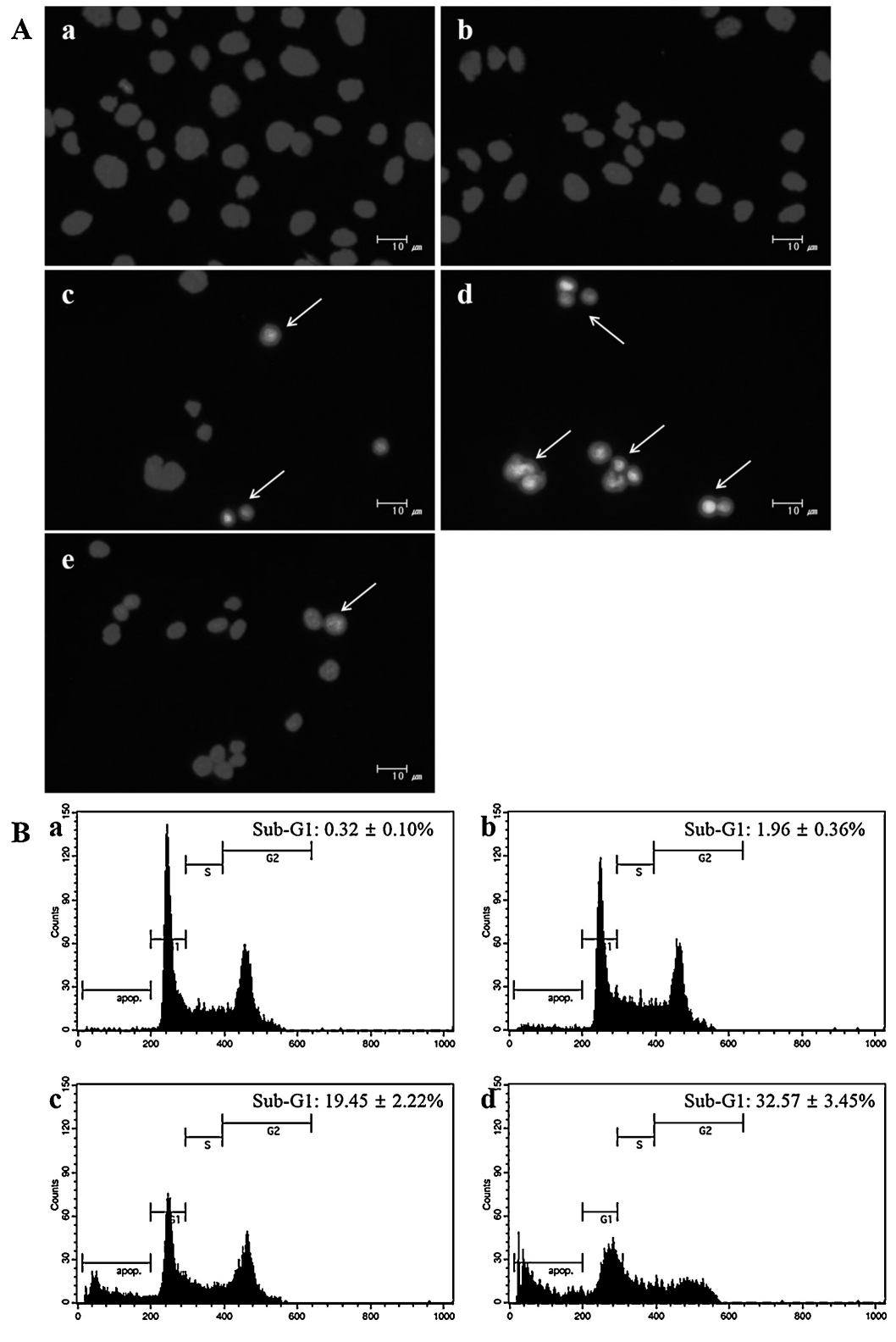

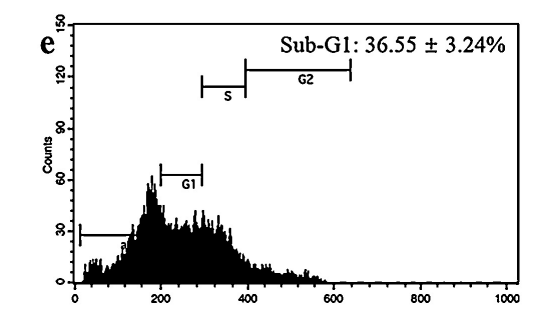

Fig. 3. Alnus japonica ethanol (AJE) extract causes AGS cell accumulation in the sub-G1 phase of the cell cycle. The Cells were treated with (a) 0 , (b) AJE $50 \mu g / m l$, (c) AJE $100 \mu \mathrm{g} / \mathrm{ml}$, (d) AJE $150 \mu \mathrm{g} / \mathrm{ml}$, and (e) doxorubicin ( $2 \mu \mathrm{M}$ ) for $24 \mathrm{~h}$. (A) Morphological analysis of the nucleus was evaluated by Hoechst 33342 staining. Condensed and fragmented nuclei were observed under a fluorescent microscope. Photographs were taken using a fluorescence microscope at $200 \times$ magnification. The arrows indicate chromatin condensation and nuclear fragmentation. Scale bar: $10 \mu \mathrm{m}$. (B) The effect of AJE extract on AGS cell cycle distribution. Histograms show the cell number per channel (vertical axis) vs. the DNA content (horizontal axis). 

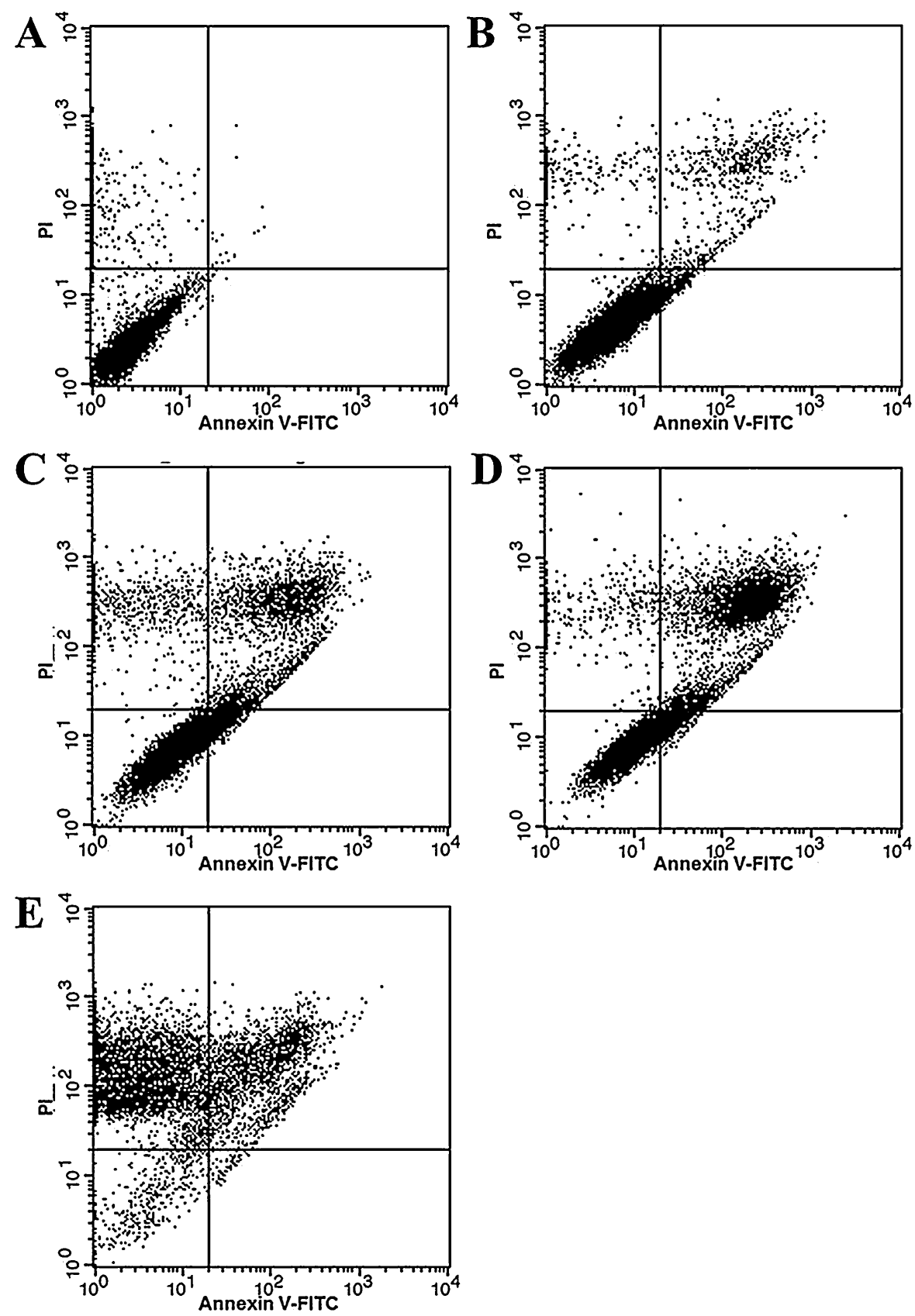

Fig. 4. The effect of Alnus japonica ethanol (AJE) extract on annexin V-FITC and propidium iodide (PI) counterstaining. The cells were treated with (A) 0, (B) AJE $50 \mu g / m l$, (C) AJE $100 \mu \mathrm{g} / \mathrm{ml}$, (D) AJE $150 \mu \mathrm{g} / \mathrm{ml}$, and (E) doxorubicin $(2 \mu \mathrm{M})$ for $24 \mathrm{~h}$. Annexin V-FITC/PI double staining was analyzed by flow cytometry. Histograms show the cell number per PI fluorescence (vertical axis) vs. the cell number per annexin V-FITC fluorescence (horizontal axis).

AJE $150 \mu \mathrm{g} / \mathrm{ml} ; 4.0 \pm 0.2$ ) (Fig. 2B). Doxorubicin is commercial anticancer compound. These results demonstrate that AJE extract induces morphological changes and cell death in AGS cells.

\section{Effects of AJE extract on the cell cycle}

Flow cytometric analysis and Hoechst 33342 staining assay were performed to analyse the AJE extract induced AGS cell death mediated through the induction of apoptosis. Our results revealed that untreated control cells displayed normal, round nuclei, while cells treated with high concentration of AJE extract exhibited more condensed and fragmented chromatin and bright blue nuclei (Fig. 3A). All the above observations indicate that AJE extract could induce apoptosis or necrosis in AGS cells. In general, when the cells are exposed to toxicants, there should be a distinct increase in the percentage of cells with a sub-G1 DNA content, which is considered to be an indicator of cell damage (Carvalho et al., 2012). In this study, we examined the influence of AJE extract on cell cycle distribution using flow cytometry. Apoptotic nuclei were observed as a sub-diploid DNA peak (sub-G1) and they were 
distinguished from cell debris based on PI fluorescence and forward light scatter (Fig. 3B). The percentage of cells in the sub-G1 phase was increased from $0.32 \%$ (control) to $1.96 \%(50 \mu \mathrm{g} / \mathrm{ml}$ ), $19.45 \%(100 \mu \mathrm{g} / \mathrm{ml})$ and $32.57 \%(150 \mu \mathrm{g} / \mathrm{ml})$ following $24 \mathrm{~h}$ exposure of AJE extract. These results suggest that AJE extract causes cell accumulation in the sub-G1 phase of the cell cycle.

\section{Effects of AJE extract on apoptosis in AGS cells}

In the present study, we performed the annexin V-FITC/PI staining assay to further confirm the apoptosis induced by AJE extract. As shown in Fig. 4, AJE extract induced apoptosis in AGS cells in a dose-dependent manner. When the cells were exposed to AJE extract at different concentrations for $24 \mathrm{~h}$, the proportion of AV+/PI- (early apoptosis) cells was increased from 0.09\% to $9.09 \%$, and the number of $\mathrm{AV}+/ \mathrm{PI}+$ (late apoptosis or necrosis) cells was increased from $0.2 \%$ to $44.3 \%$ (Fig. 4). These results suggest that AJE extract effectively induces apoptosis in AGS cells.

\section{Cellular ROS generation}

Recently, several researchers have compared normal and cancer cells under increased oxidative stress. Oxidative stress is often associated with alterations in metabolic activities and increased ROS generation. In addition, elevated ROS in cancer cells have significant consequences, such as the promotion of mutations, stimulation of cellular proliferation, genetic instability and alterations in cellular sensitivity to anticancer agents and apoptosis (Behrend et al., 2003; Kang and Hamasaki, 2003). In the present study, we also examined the intracellular ROS generation induced by AJE extract treatment at various concentrations in AGS cells. The purpose of this assessment was to determine whether AJE extract-induced apoptosis is associated with elevated ROS levels. As shown in Fig. 5, AGS cells incubated with AJE extract for $24 \mathrm{~h}$ displayed a significant, does-dependent increase in DCF fluorescence. Therefore, these results strongly suggest that AJE extract promotes intracellular ROS generation which plays an essential role in the induction of apoptotic cell death in AGS cells.

\section{Activation of caspases and PARP in AGS cells}

We examined the expression levels of pro-apoptotic family protein Bax and pro-survival family protein Bcl-2 to investigate whether these proteins are involved in regulating AJE extractinduced apoptosis in AGS cells. The anti-apoptotic Bcl-2 protein family acts as a repressor of apoptosis by blocking the release of cytochrome-c, whereas the pro-apoptotic protein family acts as a promoter of the extrinsic and intrinsic apoptotic pathways. These effects are more dependent on the balance between Bcl-2 and Bax than on Bcl-2 quantity alone (Reed, 1997). In the present study, however, AJE extract treatment could not significantly alter the
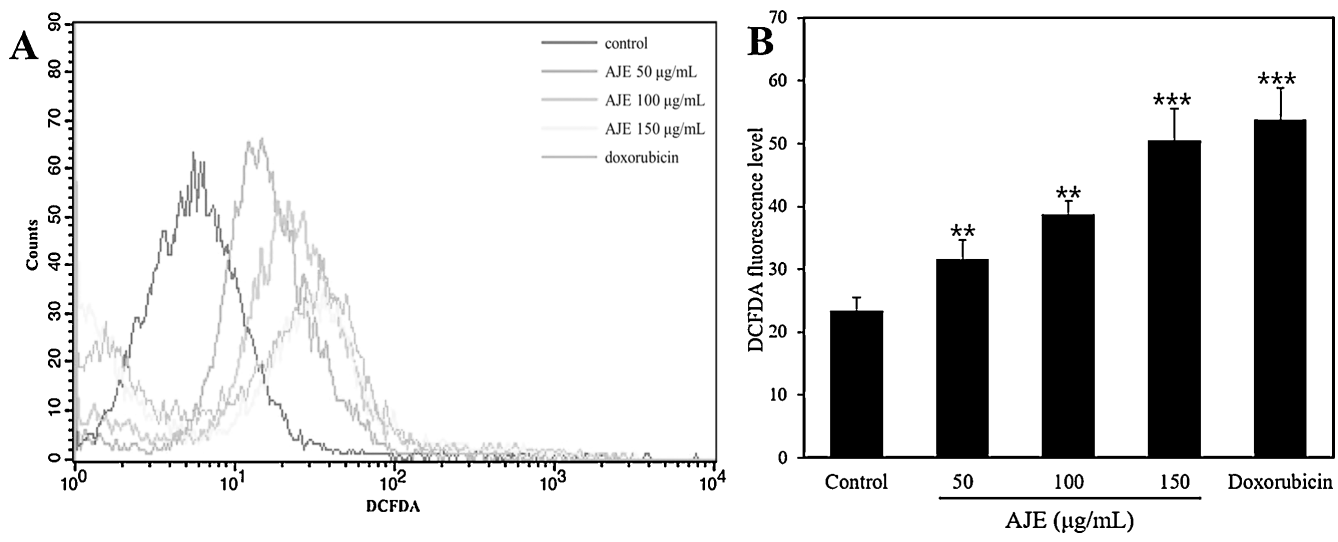

Fig. 5. The effect of Alnus japonica ethanol (AJE) extract on intracellular ROS levels in AGS cells. (A) Histograms show the cell number per channel (vertical axis) vs. the $\left(2^{\prime}, 7^{\prime}\right.$-dichlorofluorescein diacetate) DCFDA fluorescence (horizontal axis). (B) ROS levels expressed as the mean \pm SD intensity of cell fluorescence. ${ }^{* *} p<.01$, ${ }^{* * *} p<.001$ vs. control.

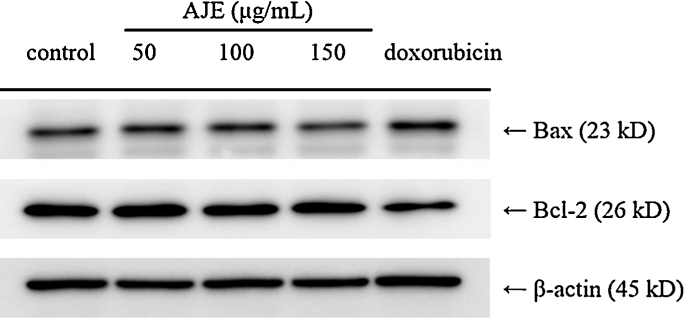

B

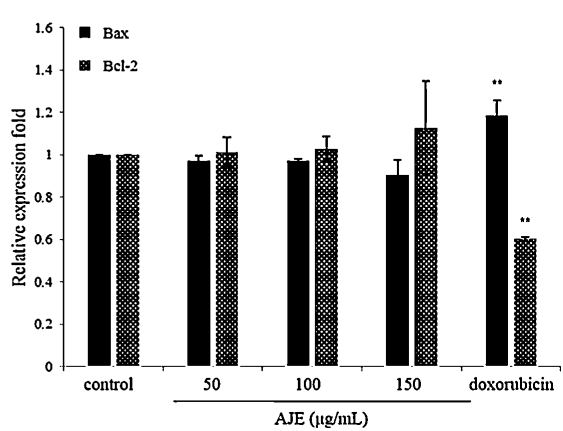

Fig. 6. The effect of Alnus japonica ethanol (AJE) extract on the expression levels of Bax and Bcl- 2 proteins in AGS cells. The cells were treated with $0,50,100$, or $150 \mu g / m l$ of AJE extracts and doxorubicin $(2 \mu \mathrm{M})$ for $24 \mathrm{~h}$. The Cell lysates were prepared and subjected to western blot analysis. Each value is the mean \pm SD of three determinations $\left({ }^{* *} p<.01\right.$ vs. control). 
$\mathbf{A}$

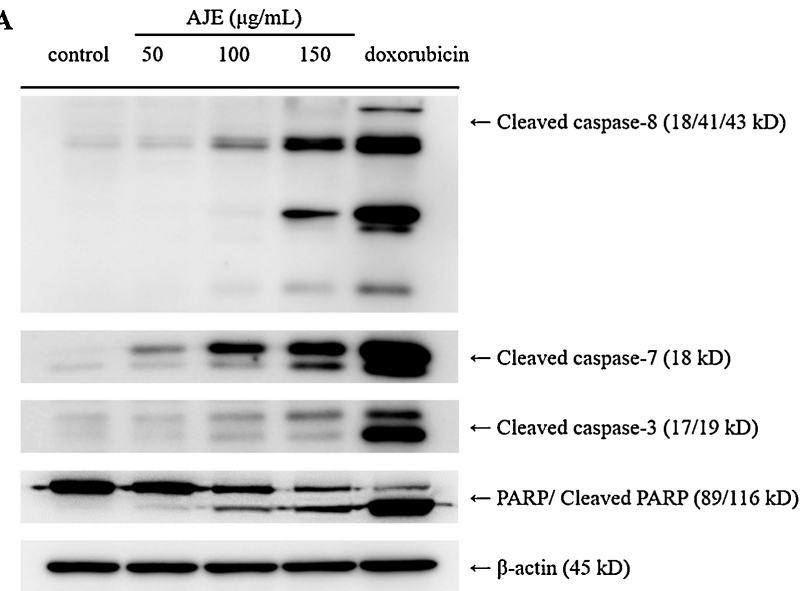

B

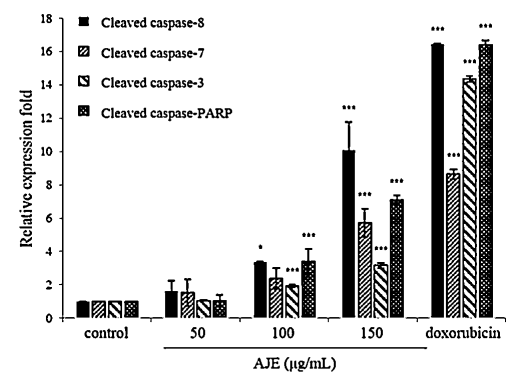

Fig. 7. The effect of Alnus japonica ethanol (AJE) extract on the expression levels of caspases and poly (ADP-ribose) polymerase (PARP) in AGS cells. The cell lysates were prepared and subjected to western blot analysis to detect apoptosis related cleaved caspase-8, 7,3 , and PARP/cleaved PARP. Each value is the mean \pm SD of three determinations $\left({ }^{* * *} p<.001\right.$ vs. control).

protein expression levels of Bax and Bcl-2 proteins (Fig. 6). These results were closely similar to the results of the earlier study (Gross et al., 1999) and our results reveal that AJE extract-induced apoptosis is mitochondria-independent.

The activation of caspases-3, 6, 7, 8, and 9 is essential for both extrinsic and intrinsic apoptotic pathways (Fulda and Debatin, 2006). We also assessed the effects of AJE extract on the activation of various caspases and cleaved PARP. PARP seems to be involved in DNA repair in response to apoptotic signal stimulation, and it serves as a marker for cells undergoing apoptosis (Oliver et al., 1998). Our results showed that AJE extract could effectively induce the cleavage the caspase-8, 7, 3, and PARP/cleaved PARP in a dosedependent manner (Fig. 7). Based on these results, we strongly suggest that AJE extracts induce the apoptotic cell death through the caspase-dependent pathway in AGS cells.

This activity might be attributed to the antioxidant and free radical scavenging properties of AJE extract. This is the first report on AJE extract cytotoxicity in AGS human gastric carcinoma cells, and these findings indicate that the extracts are potential for anticancer therapy. Further studies on the isolation, identification of bioactive compounds of $A$. japonica and their effects on in vivo model are needed for better understanding of their mechanisms of action.

\section{Conclusion}

In the present study, we evaluated the in vitro antioxidant and anticancer effects of $A$. japonica extracts in AGS human gastric carcinoma cells. The ethanol extract of $A$. japonica (AJE) showed strong antioxidant activities and induced cellular ROS generation. AJE extract inhibited cell viability and induced the cell death related morphological changes and cell death in AGS cells, in contrast, AJE extract had no effect on non-tumorigenic cells. Moreover, AJE extract induced apoptosis through the caspasedependent pathway. Thus, these results suggest that AJE extract could be potentially useful as a new promising strategy in the therapy for gastric carcinoma cancer.

\section{Conflict of interests}

The authors declare no conflict of interests regarding this article.

\section{Acknowledgement}

This work was supported by a special grant from Konkuk University.

\section{References}

Ahmad, N., Adhami, V.M., Afaq, F., Feyes, D.K., Mukhtar, H., 2001. Resveratrol causes WAF-1/p21-mediated G(1)-phase arrest of cell cycle and induction of apoptosis in human epidermoid carcinoma A431 cells. Clin. Cancer Res. 7, 1466-1473.

Ali, I., Wani, W.A., Saleem, K., Haque, A., 2013. Platinum compounds: a hope for future cancer chemotherapy. Anti-Cancer Agents Med. Chem. 13, 296-306.

Behrend, L., Henderson, G., Zwacka, R.M., 2003. Reactive oxygen species in oncogenic transformation. Biochem. Soc. Trans. 31, 1441-1444.

Benzie, I.F., Strain, J.J., 1996. The ferric reducing ability of plasma (FRAP) as a measure of antioxidant power: the FRAP assay. Anal. Biochem. 239, 70-76.

Carvalho, A.J.S., Ishikawa, T., Gouvêa, C.M.C.P., 2012. Aqueous extract of Plinia edulis leaves: Antioxidant activity and cytotoxicity to human breast cancer MCF-7 cell line. S. Afr. J. Bot. 81, 1-7.

Clere, N., Faure, S., Martinez, M.C., Andriantsitohaina, R., 2011. Anticancer properties of flavonoids: roles in various stages of carcinogenesis. Cardiovasc. Hematol. Agents. Med. Chem. 9, 62-77.

Ekwall, B., Silano, V., Paganuzzi-Stammati, A., Zucco, F., 1990. Toxicity tests with mammalian cell cultures. In: Bourdeau, E., Somers, G., Richardson, M., Hickman, J.R. (Eds.), Short-Term Toxicity Tests for Non-Genotoxic Effects. John Wiley and Sons Inc., New York, pp. 75-97.

Fulda, S., Debatin, K.M., 2006. Extrinsic versus intrinsic apoptosis pathways in anticancer chemotherapy. Oncogene 25, 4798-4811.

Ghobrial, I.M., Witzig, T.E., Adjei, A.A., 2005. Targeting apoptosis pathways in cancer therapy. CA-Cancer J. Clin. 55, 178-194.

Gross, A., McDonnell, J.M., Korsmeyer, S.J., 1999. BCL-2 family members and the mitochondria in apoptosis. Genes Dev. 13, 1899-1911.

Halliwell, B., 2007. Oxidative stress and cancer: have we moved forward? Biochem. J. 401, 1-11.

Heo, B.G., Park, Y.J., Park, Y.S., Bae, J.H., Cho, J.Y., Park, K., et al., 2014. Anticancer and antioxidant effects of extracts from different parts of indigo plant. Ind. Crop. Prod. 56, 9-16.

Jemal, A., Bray, F., Center, M.M., Ferlay, J., Ward, E., Forman, D., 2011. Global cancer statistics. CA-Cancer J. Clin. 61, 69-90.

Joo, S.S., Kim, S.G., Choi, S.E., Kim, Y.B., Park, H.Y., Seo, S.J., et al., 2009. Suppression of T cell activation by hirsutenone, isolated from the bark of Alnus japonica, and its therapeutic advantages for atopic dermatitis. Eur. J. Pharmacol. 614, 98-105.

Kang, D., Hamasaki, N., 2003. Mitochondrial oxidative stress and mitochondrial DNA. Clin. Chem. Lab. Med. 41, 1281-1288.

Kim, S.T., Kim, J.D., Ahn, S.H., Ahn, G.S., Lee, Y.I., Jeong, Y.S., 2004. Hepatoprotective and antioxidant effects of Alnus japonica extracts on acetaminophen-induced hepatotoxicity in rats. Phytother. Res. 18, 971-975.

Kim, Y.S., Lee, S.J., Hwang, J.W., Kim, E.K., Kim, S.E., Kim, E.W., et al., 2012. In vitro protective effects of Thymus quinquecostatus Celak extracts on $t$-BHP-induced cell damage through antioxidant activity. Food Chem. Toxicol. 50, 4191-4198.

Kim, Y.S., Hwang, J.W., Han, Y.K., Kwon, H.J., Hong, H., Kim, E.H., et al., 2014. Antioxidant activity and protective effects of Trapa japonica pericarp extracts 
against tert-butylhydroperoxide-induced oxidative damage in Chang cells. Food Chem. Toxicol. 64, 49-56.

Lee, S.J., 1966. Korean Folk Medicine. Pub. Center of Seoul National University.

Leite de Oliveira, R., Deschoemaeker, S., Henze, A.T., Debackere, K., Finisguerra, V., Takeda, Y., et al., 2012. Gene-targeting of Phd2 improves tumour response to chemotherapy and prevents side-toxicity. Cancer Cell. 22, 263-277.

Milaeva, E.R., 2011. Metal-based antioxidants - potential therapeutic candidates for prevention the oxidative stress-related carcinogenesis: mini-review. Curr. Top. Med. Chem. 11, 2703-2713.

Nanjo, F., Goto, K., Seto, R., Suzuki, M., Sakai, M., Hara, Y., 1996. Scavenging effects of tea catechins and their derivatives on 1,1-diphenyl-2-picrylhydrazyl radical. Free Radic. Biol. Med. 21, 895-902.

Oliver, F.J., de la Rubia, G., Rolli, V., Ruiz-Ruiz, M.C., de Murcia, G., Murcia, J.M., 1998. Importance of poly (ADP-ribose) polymerase and its cleavage in apoptosis. Lesson from an uncleavable mutant. J. Biol. Chem. 273, 33533-33539.

Re, R., Pellegrini, N., Proteggente, A., Pannala, A., Yang, M., Rice-Evans, C., 1999. Antioxidant activity applying an improved ABTS radical cation decolorization assay. Free Radic. Biol. Med. 26, 1231-1237.
Reed, J.C., 1997. Bcl-2 family proteins: regulators of apoptosis and chemoresistance in hematologic malignancies. Semin. Hematol. 34, 9-19.

Sieniawska, E., Baj, T., Dudka, J., Gieroba, R., Swiatek, L., Rajtar, B., et al., 2013.

Cytotoxicity: antioxidant activity and an effect on CYP3A4 and CYP2D6 of Mutellina purpurea L. extracts. Food Chem. Toxicol. 52, 188-192.

Singleton, V.L., Orthofer, R., Lamuela-Raventos, R.M., 1999. Analysis of total phenols and other oxidation substrates and antioxidants by means of Folin-Ciocalteu reagent. Methods Enzymol. 299, 152-178.

Zhang, H., Sun, K., Ding, J., Xu, H., Zhu, L., Zhang, K., et al., 2013. Harmine induces apoptosis and inhibits tumor cell proliferation: migration and invasion through down-regulation of cyclooxygenase-2 expression in gastric cancer. Phytomedicine 21, 348-355.

Zhishen, J., Mengcheng, T., Jianming, W., 1999. The determination of flavonoid contents in mulberry and their scavenging effects on superoxide radicals. Food Chem. 64, 555-559. 